\title{
The perfect philosophy for the perfect generation. (Effective Altruism : everywhere but at home.)
}

\author{
Camille Akmut
}

\begin{abstract}
A report on a peculiar philosophy of our times. It has enabled countless high-earners and 1-percenters to justify their lifestyles, particularly in technology and financial/quantitative circles. They do so by giving back intermittently to faraway lands, hence our choice of title "Everywhere but at home". We look at its foundations, its main promoters, the institutions they are associated with and from which they draw their false aura. We argue that Peter Singer et al. may have finally found a solution to what we call the Galbraith equation : the fitting moral justification of greed. Every age deserves its set of new philosophies : "Effective Altruism" is that of Facebook, Jane Street, Two Sigma and co..
\end{abstract}


"By being around a lot of wealthy people who drive Ferraris, I would soon say, never mind about the charities, what I really want is a Ferrari." (The Most Good You Can Do) 


\section{Introduction}

If the quality or worth of a philosophy should be measured by its proponents, that of "Effective Altruism" can be no good.

Rarely has an ideology drawn such wide acclaim, and specifically by the particular audience constituted by various bankers, "quants" (quantitative analysts), corporate entities, corporate data scientists, engineers, analysts, and the like.

But, we will do the most good we can in rendering its principles, tenets, and tenors ${ }^{1}$, and the sets of moral casuistic it forms.

But, in doing so, we always keep in mind the question, and invite the reader to do likewise : why would such a philosophy find such universal acclaim with the public we know it to be particularly popular with? For, it can indeed be said that no other philosophy, other than that of capitalism, if it can be said to constitute such a thing, has enthused bankers as much as "Effective Altruism" has.

In the case of Peter Singer et al. and their literature, all the stars must have been aligned : they are employed by Oxford, their books are published by Yale Press, their ideas fit the moods of our times to perfection, receiving the equivalent of standing ovations from Facebook to the new class of technology investment firms.

Much ought to be said about the current role and situation of philosophers : gone the days of imperial reign of their discipline during the times of Kant or $\mathrm{Hegel}^{2}$, they must indeed do the best they can with the little they have left. In the face of the emergence of the various social sciences, which have adequately subsumed many of their domains under theirs - from sociology to economics - they must reinvent themselves times and times again, "bio-ethicists", "techno-ethicists", "trans-humanist philosophers", "AI thinkers", etc. etc.

In the future, it can be expected that - computer scientists now added to the mix - their domain will be like that described in the last pages of Foucault's inquiry into the epistemology of the human sciences : a drawing on sand disappearing amidst fluctuating waters.

In this age, they still have a role to play however : Peter Singer et al.'s may have been to have provided a long sought answer - and thus closing a long search - for one of the oldest problems of human kind, moral justifications to greed.

Their ideas provided the missing key. "Effective Altruism" can be said with no doubt to represent to our new technological elites, the same as the specific strands of Protestantism described in Weber's study on the origins of capitalism.

The emergence of new classes, of objects, individuals, structures,

\footnotetext{
${ }^{1}$ One may almost wish to write tenants due to the very specific corporate style and allures of this philosophy.

${ }^{2}$ In his writings on the problem of "the faculties", Kant, a philosopher, concluded that due to various reasons of his own making, philosophy should be the foundation of all other sciences - such ideas, some of them very queer, have accompanied much of the development of philosophy. Much more interesting, or banal will be its end.
} 
and institutions, within our societies - the class of merchants during the Middle ages, that of factory owners in the manner of Manchester capitalism during the 19th century, the call centers of the 1980s, and the Internet companies of the 1990s - all required new ideas to make sense of them.

Some were there to comfort and make normal their existence, some constituted tools of liberation, others just came in the form of ad-hoc justifications.

\section{The Most Good You Can Do reading notes}

When Weber looked for the origins of Capitalism - whose major achievement was not to have looked for economic reasons as would have seemed perhaps the obvious answer but for their philosophical or ethical underpinnings - he found them not in Protestant ethics in general, but in certain strands that encouraged active lifestyles, and promoted various rules (getting up early, going to bed early, giving oneself entirely to one's daily tasks etc.), that provided the "soil" for the ideas and practices of capitalism to grow on, and were its "vehicles" 3.

In The Most Good You Can Do, the equivalent of Weber's various ethical and moral text sources, we turn particularly to section two, and the chapters entitled "Earning to Give" that are contrasted with "Living Modestly", "Other Ethical Careers" and "Giving a Part of Yourself" (with "Earning to Give" being the key chapter here ${ }^{4}$ ).

The main tenet or doctrine need not be searched for long, for it is presented, and presents itself on the very first page of this chapter, in this book of moral casuistic tales :

Although it is possible to earn an average income and still donate enough to do a lot of good, it remains true that the more you earn, the more you can donate. ${ }^{5}$

This succeeds the chapter on "Living Modestly" which opens with the real-example example of a particular woman who gave a lot to charities despite earning relatively little. Ergo : this is commendable, but not the way to go.

This chapter however opens with another example, Jim Greenbaum, founder of a telecommunications company, whose many trials and errors are explained to us - having hesitated between direct action (i.e. going to a country in need and helping) and other various ways.

But, these various Platonic fables already foretell their teachings : the real way to go is that of founding a technology company, selling it and giving away money.

\footnotetext{
${ }^{3}$ We use about Weber's terminology here.

4 "Living Modestly" would have been unlikely to have had the same appeal to the various aforementioned individuals and companies for obvious reasons (they do not practice modesty much, so little that drawing on the writings of the economist Thomas Piketty even journalists from mainstream publications began to call them, their lifestyles and their actions "a-social" around the time of the publication of Capital ...).

${ }^{5}$ P. 39.
} 
Everything is so plain, and clear in Singer's strange philosophy that there is no need for hermeneutics : Weber went through much trouble rendering the preoccupations of his text sources' writers to his contemporary audience, and we must go through the additional steps of understanding his, but no thing such can be said to be true here.

Jim lives an affluent life and lives in a luxurious home. He once owned a few sports cars and a share in a private jet but soon came to see those as excesses. While he now drives a Toyota, he still struggles to find a balance between his lifestyle and using his money to help others. ${ }^{6}$

The explanations, and the motives are so simple - no headaches involved in separating Sein from Dasein, or Existence from Living that any commentary is almost unnecessary, no more than a CocaCola, or Pepsi ad, or Mars bar ad requires one.

Working in finance, however, you earn much more than you need and give half of your earnings to the charity, which can use that money to employ two extra workers it would not, without your donation ${ }^{7}$

Previous generations of philosophers gave us much trouble with their terminology : to make sense of their writings, one had to go through the complex task of uncovering their terms. Though, sometimes their ideas were equally simple underneath all the jargon as here.

Commentaries are futile when philosophy reads like financial manuals. Except, we learn here that besides founding a telecom' company, a good life is constituted by "working in finance", words that will be like candies in the mouth of a boy too big for his size for all the bankers, quants and others of this world.

most of those earning to give are from the generation that started to think about their career choices around the turn of the millennium. ${ }^{8}$

Ergo, the technological elite.

Ian then began to put that logic into practice in his own life. He worked for four years at McKinsey, the management consultants, and then at the Disney Corporation before moving to a more senior role in a video gaming startup. ${ }^{9}$

Of which one example.

In 2013 an article in the Washington Post featured Jason Trigg, an MIT computer science graduate working in finance and giving half of his salary to the Against Malaria Foundation. ${ }^{10}$

\footnotetext{
${ }^{6}$ P. 40.

${ }^{7}$ P. 41.

${ }^{8}$ P. 42.

${ }^{9}$ P. 44.

${ }^{10}$ P. 45.
} 
More examples from the technological world. Endearing tales.

A Ferrari is still not on Matts shopping list. His strategy for trying to prevent it ever getting there is to be very public about his pledge to donate 50 percent of his income. He has told all his friends that if he doesnt keep his pledge, they should ridicule him. ${ }^{11}$

Another tenor of this queer philosophy is "star philosopher" (the equivalent of the "rock star" programmers of the programming world, except in the world of philosophy) Will MacAskill. But, we leave to others the truly tiresome task of working through their strange writings.

\section{Conclusion}

A philosophy that - if it had not been invented by philosophers could have been easily attributable to any of the content managers, or community managers at Microsoft, Apple or such.

Such a philosophy, in turn with no surprise appealing to these same companies and their employees who could have written their tenets (make a lot, give some away), leaves one stupendous.

There can be no commentary for a philosophy that gives its motives and principles so readily away.

Philosophy will soon likely play no big role in our societies anymore. But, it still does and so we turned to it once more. As for the rest :

Corporate software engineers may well become the bankers of tomorrow, if they are not already today. Though not quite yet in popular consciousness, but, that will come however - it is up to them to decide what role they will play, and how the rest of us will perceive them.

But, they will not find answers in the books that are tailor-made for them. In this study, we gave (interrupted) reading notes on one of them.

"You have paid the tithe on one tenth of your mint, dill, and cumin but have neglected more important matters: justice, mercy and honour. You should have done these things without neglecting the others."

\footnotetext{
${ }^{11}$ P. 46.
} 


\section{Bibliography}

Singer, Peter. 2015. The Most Good You Can Do. Yale Press.

MacAskill, Will. 2016. Doing Good Better. Avery. 